\title{
International Year of Chemistry
}

DOI: $10.1134 / \mathrm{S} 1061934810080010$

According to the decision of the United Nations Organization, 2011 was declared the International Year of Chemistry (IYC). This decision was preceded by the recommendations of the International Union of Pure and Applied Chemistry (IUPAC) and UNESCO, and the initiative in due time came from Russian chemists. The aim of IYC is to attract the attention of the society and the states to chemical science and chemical industry; to assist the popularization of chemistry, especially among young people; and to stimulate those who already work in chemistry.

The plans for the celebration of IYC were prepared by IUPAC, UNESCO, the European Association of Chemical and Molecular Sciences (EuCheMS), some other international organizations, and also large national chemical societies.

The official opening ceremony of the Year of Chemistry is scheduled for January 27-28, 2011. On these days, a large forum will be organized in Paris under the aegis of UNESCO, in which lectures will be presented, and round-table discussions will be held. The main topics of the Forum will be the following: chemistry and the society, chemistry and global problems (health, energy, materials, environment, cli- mate), chemistry and the origin of life, women in chemistry, etc. Active participation of young chemists is anticipated.

Some current events will also be dedicated to the Year of Chemistry. Among these are the Pacific Chemical Congress in December 2010, the next IUPAC Congress in Puerto Rico in July-August 2011, and others. EuCheMS' plans include publishing books in chemistry for children and making pictures; exhibitions, excursions, and olympiads will also be organized.

For Russia, 2011 is also important because we will celebrate the 300th anniversary from the birth of our first chemist M.V. Lomonosov.

Russian plans for 2011 include the XIX Mendeleev Congress on General and Applied Chemistry, the congress of teachers of chemistry, a competition on the most popular papers on chemistry, and also olympiads, exhibitions, scientific conferences, and awards. It would be good to equip school chemical class rooms in the Year of Chemistry.

Yu.A. Zolotov 